\title{
DETERMINATION OF THE ECONOMIC EFFECTS IN INTESIVE PRODUCTION OF PIGLETS
}

\author{
Milorad Mirilovićn ${ }^{1}$, Branko Velebit ${ }^{2}$, Spomenka Djurić ${ }^{1}$, Branislav Vejnović1, \\ Mirjana Dimitrijević ${ }^{1}$, Nada Tajdić ${ }^{1}$, Dragan Rogožarski ${ }^{3}$ \\ ${ }^{1}$ Faculty of Veterinary Medicine, University of Belgrade, \\ Bulevar Oslobodjenja 18, Belgrade, Serbia \\ ${ }^{2}$ Institute of Meat Hygiene and Technology, Kacanskog 13, Belgrade, Serbia \\ ${ }^{3}$ Veterinary Specialist Institute "Pozarevac", Dunavska 89, Pozarevac, Serbia
}

Received 2 March 2016; Received in revised form 8 June 2016; Accepted 15 July 2016

\begin{abstract}
Critical indicators of intensive production in hog raising are continuity of production, high level of produced series-tours, application of the most contemporary technological achievements without any turnover of capital, high merchandise turnover, and intensive usage of the reproduction potential of breeding material. Production of piglets represents one of the most essential phases in the production of pork meat. In spite of genetic factors, duration of interval wean-conception is one of the basic factors in determination of bringing forth indexes and number of piglets per litter. In order to recognize production costs of piglets completely we found nutrition costs for piglets and sows represent $61 \%$, while other costs such as personal incomes, veterinary services, water, energy, losses, and amortization represent $39 \%$ of total costs. On the basis of cost price per feeding day of a sow and the number of piglets per litter, production costs of piglets older than 28 days with an average body weight of $7 \mathrm{~kg}$ were determined. Price cost per piglet after weaning, with $7 \mathrm{~kg}$ average body weight, and 146 days of reproduction process accounts for 21,78 EUR if there are 10 piglets in a litter. If the reproductive cycle would last exactly the same and if successful conception would be achieved 25 days after weaning, production cost per piglet would be 23,79 EUR.
\end{abstract}

Key words: economy, production of piglets, litter size, nutrition

\section{INTRODUCTION}

Hog raising production, under present market competition, must possess all the characteristics of developed industrial production. Crucial indicators of such production are as follows: continuity, high level of production series-shifts, application of the most up-to date technological achievements, fast turn-over of capital, high fertility, and intensive usage of breeding material reproduction potential. Genetic factors are among the most important

Corresponding author: Assoc. Prof. Milorad Mirilović, $\mathrm{PhD}$ E-mail address:mija@vet.bg.ac.rs

Present address: Department of Economics and Statistics

Faculty of Veterinary Medicine University of Belgrade, Bulevar Oslobođenja 1811000 Belgrade, Serbia

Phone: $+++381112685551 ;+381113615436$ ext: $256 ; 382$

Copyright: (C) 2016 Mirilović M. This is an open-access article published under the terms of the Creative Commons Attribution License which permits unrestricted use, distribution, and reproduction in any medium, provided the original author and source are credited.

Competing Interests: The authors have declared that no competing interests exist.

Available Online First: 15 August 2016

Published on: 15 October 2016

http://dx.doi.org/10.1515/macvetrev-2016-0090 factors influencing the increase of reproduction and production characteristics in hogs (1). Proper selection of gilts and breeding boars provides better results and decreases reproductive disorders such as: (ovulation disorders, embryo resorption, cysts on ovaries, spermatogenesis disorders). Size of litter is also highly dependent on the genetic properties of boars and gilts (2), while new technological achievements enable harmonization of paragenetic factors during upbringing and nursing of sucklingpigs, in nutrition and zootehnical solutions, but also render suckling period shorter and provide maximum usage of all genetic potentials in hog raising production. Appropriate feeding of all categories of hogs represents the most important paragenetic factor (3). Properly balanced meal, both in quality and quantity, leads to the improvement of both reproductive and productive indicators in hog raising production.

From an economic point of view, production of suckling-pigs should be as cheap as possible, while being the fastest and most qualitative under given 
conditions in order to provide positive economic effects, that is, to enable profit. Production of pork in modern industrial objects mostly depends on reproduction results, because the number of suckling-pigs per sow has direct influence on number of fattened pigs, as well as on the quantity of meat. Production results on some industrial farms are such that 26 suckling-pigs are obtained per sow yearly, namely 1800 up to $2000 \mathrm{~kg}$ of raw material and 900 up to $1010 \mathrm{~kg}$ of meat. Number of fattened pig per saw reaches yearly more than 25 (4).

Production of suckling-pigs is burdened by considerable financial costs (loans, interest rates, incomes, amortization) and it is therefore necessary that all genetic and technological factors are rationally used in order to get as high as possible number of suckling-pigs per production unit, and as well as quantity of meat (5). Economic efficiency of the piglet production is highly affected by technological factors, such as hygiene of the stable, gilt and sow rearing hygiene and, in particular, regular sanitation of udder and teats of lactating sows which improves survival and vitality of piglets during the lactation period (6).

\section{MATERIAL AND METHODS}

The aim of this investigation was to present the possibilities and the economic effects of sucklingpig production under intensive raising conditions. Our essential intention was to find out the necessary parameters for improved economic and productive indicators, namely to find out the border profitability in relation to the numbers of suckling-pigs per litter and the length of weaning period of suckling-pigs up to successful insemination or mating. When the length of reproduction cycle of sows was analyzed it was found out that it consisted of two parts:

- Nonproductive phase, which lasts from weaning until successful artificial insemination (mating) - weaning/mating interval. This phase is variable and reproduction results of a sow mostly depend on its length of bearing young. The length of this phase can be significantly easier to deal with rather than with genetic reproduction factors (7).

- Productive phase is the phase that lasts from successful fertilization till the end of the lactation period. If the length of the lactation period is limited to 28 days, this phase lasts 143 days (115 days of gestation and 28 days suckling period) (8).

During the calculation of production costs for suckling-pigs in our study, we took the day of artificial insemination (mating) as the first day of a cycle. When we wanted to determine the total costs per sow, the following parameters were taken into 234 account: average sow weight approximately $200 \mathrm{~kg}$, farrow parity 3-5 and ca. 10 suckling-pigs, body weight at weaning were approximately $7 \mathrm{~kg}(9)$.

As a model for the establishment of the reproductive-economic indicators for this study, we used an industrial farm with a capacity of 25 to 30 thousand fattening pigs per year. The farm has 1.500 sows and 25 boars. For reproduction they have used an F1-generation of breeding sows, that have arisen by crossing Yorkshire and Landrace. The sows are housed in the waiting area in small groups (5-7 heads), while during the farrowing they are placed in individual boxes with fixing. All facilities have a partially slatted floor and are with installed ventilation systems. For nutrition on the farm corn, barley and triticale are used as energy nutrients, while soybean meal and soybean cake as protein nutrients. The premix is produced in ther own facilities.

For determination of the economic factors associated with the production of suckling-pigs, it was necessary to find out the relevant indicators for regular and real estimation of costs in sucklingpig production, as well as to establish all profit indicators for this production. This paper reviews all costs which burden the product unit (feed, amortization of veterinary services, etc.), with focus on the analysis of the expenses for pregnant sows, sows in lactation and supplementary suckling-pig feeding during the nursing period.

Descriptive statistical parameters were used in this study for statistical analyses of obtained results such as simple arithmetical mean, weighted average, relative structural numbers. Obtained results were statistically processed (10).

\section{RESULTS}

Determination of economic efficiency in piglet production is a highly complex process consisting of several phases. The first phase includes calculation of the total operating costs in piglet production. On the basis of our study, it has been determined that feeding costs largely contribute $(61,00 \%)$ to the total cost of production. Equipment-and-object amortization and herd renewal costs account for $17,00 \%$ of cost, while personnel incomes account for $12,00 \%$. Veterinary services and other nonspecified costs are minor and account for $8,00 \%$ and 2,00\% of total costs, respectively (Fig. 1).

Further research included determination of all relative indicators in the category of "costs during a reproductive cycle". On the basis of the participation of feed costs in the total costs and the feed mix cost price for sows (pregnant sows and 


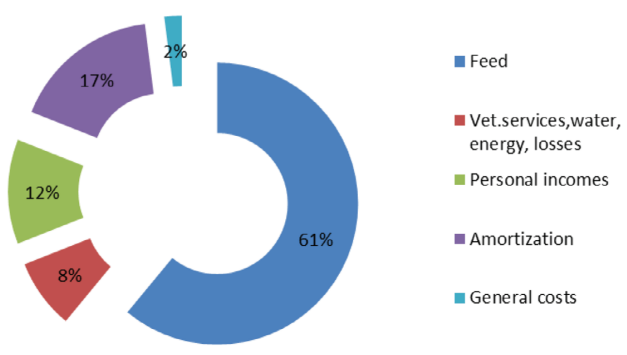

Figure1. Average costs per category in the production of pork meat

those in lactation), the feeding day per sow cost price was calculated. For precise calculation of the total quantity of feed per sow, the "flushing" method of sow feeding was applied. On the basis of these analyses, it was found out that the production phase of the reproductive cycle requires $507 \mathrm{~kg}$ of feed. Distribution of the necessary quantity of feed per phase of productive part of reproduction phase is shown in Fig. 2.

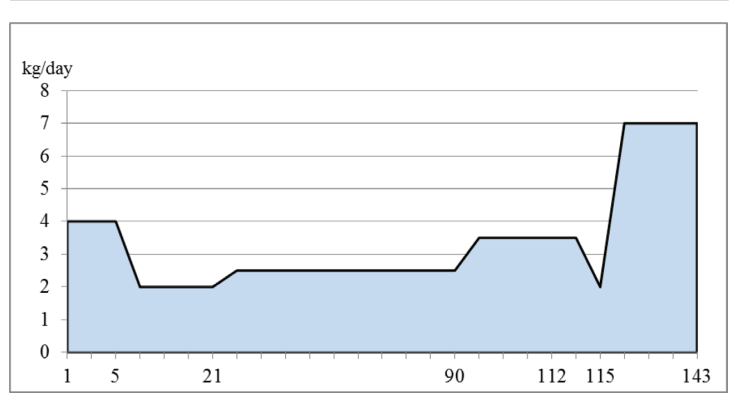

Figure 2. Sow feed consumption during a reproductive cycle

The first step in calculation of costs for a oneday sow feeding was to determine the nutritional needs for pregnant and lactating sows. These requirements are presented in Table 1. Using these facts and available fodder and feed mixes, daily portions were prepared. By analyzing the relevant categories of feed and their respective market value we determined the following facts:
- cost price per $1 \mathrm{~kg}$ of feed mix for pregnant sows was $0,22 \mathrm{EUR}$;

- cost price per $1 \mathrm{~kg}$ of feed mix for lactating sows was 0,28 EUR;

- average cost price of $1 \mathrm{~kg}$ of feed mix for sow (calculated as weighted average for both pregnant and lactating sows) was 0,24 EUR.

During the calculation of the total amount of feed required to feed a sow, the following formula has been used:

- One productive phase of the reproductive cycle (pregnancy and weaning lasting 143 days) takes 507 $\mathrm{kg}$ of feed per sow;

- During the one-year period there are at least two reproductive cycles in intense reproduction (two productive phases which equals 286 days), so a total of $1.014 \mathrm{~kg}$ feed is used;

- The remaining 79 days (365-286) are days considered as both the non-productive part of reproductive cycle and partially belonging to the third productive part of the reproductive cycle. In these 79 days, a total of $198 \mathrm{~kg}$ of feed are needed;

- Gross total amount of feed per sow per annum was $1.212 \mathrm{~kg}$;

- Gross total cost price per sow per annum was 297,74 EUR.

On the basis of the annual distribution of cost categories, we have determined that the total cost per sow per annum was 489,39 EUR. Using this data for per day calculation, we have come to the indication that one day of feeding per sow is 1,34 EUR. All this elements enabled us to calculate the manufacturing price per pig. (Fig. 3)

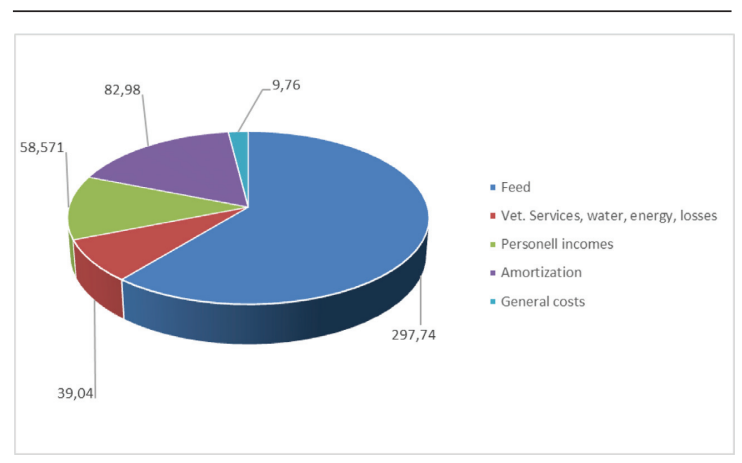

Figure 3. Structure of total costs per sow

Table 1. Nutritional requirements of sows

\begin{tabular}{lccccccccc}
\hline & $\begin{array}{c}\text { Crude } \\
\text { proteins } \\
\%\end{array}$ & $\begin{array}{c}\text { Cellulose } \\
\%\end{array}$ & $\begin{array}{c}\text { ME, } \\
\text { MJ/ } \\
\text { kg }\end{array}$ & Ca \% & P \% & Tryptophan & $\begin{array}{c}\text { Met. } \\
\text { Cist. }\end{array}$ & Lysin \% & Vit-E \\
\hline $\begin{array}{l}\text { Pregnant sow } \\
\text { Lactating } \\
\text { sows }\end{array}$ & 13.0 & $7.0-9.0$ & 11.9 & $0.8-1.0$ & $0.5-0.7$ & 0.10 & 0.30 & 0.55 & 20.0 \\
\hline
\end{tabular}


Table 2. Economic effectiveness in case litter size is 10 piglets

\begin{tabular}{llllll}
\hline Days & Cost price & Market value & Profit & Profit per year $\begin{array}{l}\text { Annual profit } \\
\text { per 200 sows }\end{array}$ \\
\hline 4 & 209,73 & 233,33 & 23,60 & 58,62 & $11.723,87$ \\
7 & 213,75 & 233,33 & 19,58 & 47,65 & $9.530,56$ \\
10 & 217,78 & 233,33 & 15,56 & 37,12 & $7.423,26$ \\
15 & 224,48 & 233,33 & 8,85 & 20,44 & $4.088,92$ \\
25 & 237,90 & 233,33 & $-4,57$ & $-9,92$ & $-1.984,33$ \\
\hline
\end{tabular}

Economic indicators for the production of two different models were investigated in this study. The first model presumes that litter has 10 weaned piglets, while weaning-conception interval duration was a variable model component. Duration of the variable interval is usually $4,7,10,15$ and 25 days.

In the second model, the weaning-conception interval duration was fixed to ten days, while the variable component was the different number of weaned piglets $(8,9,10,11$ and 12). In both models tested benefits per sow per annum were calculated, while the model was based on a farm of 200 sows in reproductive cycle.

By analyzing the economic model of piglet production in case when the number of piglets is fixed, we have determined that cost price per litter with 10 piglets' increases from 209,73 EUR (interval weaning-estrus is 4 days) to 237,90 EUR (interval weaning-estrus is 25 days). Annual net income per sow was 58,62 EUR (interval weaning-estrus is 4 days), while annual net losses of 9,92 EUR occurred if interval weaning-estrus was 25 days. If we take into consideration an average farm breeding 200 sows with interval weaning-estrus of 25 days, an economic loss of 1984,33 EUR is expected.

In case when interval weaning-estrus has been fixed to 10 days (Table 3), it appears that there has been a slight increase (4,99 EUR) in the price of litters having different number of piglets $(220,28$ EUR at 12 piglet litter vs. 215,28 EUR at 8 piglet litter). Per annum calculation indicates that sows weaning 8 piglets generate economic losses of 68,25 EUR, while sows weaning 12 piglets generate economic income of 142,48 EUR. Economic indicators for a farm of 200 sows show that the total income difference of 8 and 12 piglets per liter respectively was 42145,97 EUR per annum.

\section{DISCUSSION}

Calculation of the category of all operating costs in suckling-pig production has been a major problem. Large industrial farms possess documentation for both planned and realized calculation of production process. This documentation is not uniform, therefore the category of "expenses" differs from farm to farm. Our results can be widely applied, i.e. it can be used for calculations in future production. These are also comparable with the results obtained at 5 different piglet farms. Comparison has been performed on the basis of the participation of relative cost indicators in piglet production at two farms in Vojvodina, one farm in Eastern Serbia, and one farm in Croatia. Average costs in 9 countries of Western Europe were also taken into account.

On the basis of the obtained results, it can be observed that feeding costs are the lowest (49.87\%) in Western European countries, and the highest on farm 3 , encompassing $77.10 \%$ of all costs in

Table 3. Economic effectiveness in case when interval weaning-estrus is 10 days

\begin{tabular}{llllll}
\hline $\begin{array}{l}\text { Piglets in } \\
\text { litter }\end{array}$ & Cost price & Market value & Profit & Profit per year & $\begin{array}{l}\text { Annual profit } \\
\text { per 200 sows }\end{array}$ \\
\hline $\mathbf{8}$ & 215,28 & 186,67 & $-28,61$ & $-68,25$ & $-13.649,73$ \\
$\mathbf{9}$ & 205,28 & 210,00 & 4,73 & 11,27 & $2.254,41$ \\
$\mathbf{1 0}$ & 217,78 & 233,33 & 15,56 & 37,12 & $7.423,26$ \\
$\mathbf{1 1}$ & 219,03 & 256,67 & 37,64 & 89,80 & $17.959,75$ \\
$\mathbf{1 2}$ & 220,28 & 280,00 & 59,73 & 142,48 & $28.496,24$ \\
\hline
\end{tabular}


Economic effects in intesive piglet production

Table 4. Relative indicators in participation of certain category costs in the total production costs for pork meat

\begin{tabular}{llllll}
\hline Cost category & Farm 1 & Farm 2 & Farm 3 & Farm 4 & EU \\
\hline Feed & 57.33 & 63.00 & 77.10 & 57.00 & 49.87 \\
$\begin{array}{l}\text { Vet. services, water, } \\
\text { energy, losses }\end{array}$ & 7.65 & 10.26 & 6.27 & 6.00 & 8.61 \\
$\begin{array}{l}\text { Personal incomes } \\
\text { Amortization }\end{array}$ & 14.76 & 16.00 & 7.56 & 11.00 & 11.86 \\
General costs & 18.62 & 8.66 & 8.07 & 24.50 & 28.00 \\
TOTAL & 1.64 & 2.08 & 1.00 & 1.50 & 1.66 \\
\hline
\end{tabular}

suckling-pig production. The situation is completely different when amortization costs come in question. These costs were the highest in Western European countries $(28 \%)$ rather than farm $3(8.07 \%)$. Our study indicates that average costs for sow feeding accounted for $61 \%$ of the total costs and these were $11 \%$ higher than in EU, but in accordance with average costs in region. All other expenses such as personnel incomes, veterinary services, water, energy losses, amortization were $39 \%$ (11).

Our findings on feed consumption and feeding costs are in accordance with the findings of other authors. Aherne et al. indicate that pregnant sows require enough amount of high quality feed and prior to conception sows should be fed by concentrated feed, while 48-72 hrs. after conception sows should be fed with no more than $2,5 \mathrm{~kg}$ of feed in order to avoid embryonic death (12). Also, the cost of herd and managment exclusion is the implementation of proper and smooth production process piglets, which is the basis for a better financial result farms (13).

Calculation generated and used to devise annual cost per sow in our model indicates that these cost are 489,39 EUR, while annual costs per sow in the study of Duarte et al. are in the range of 285,97 333,29 EUR, depending on the farm and rearing methodology. By analyzing piglet value after weaning ( 28 days old), we have concluded that it ranges from 21 to 24 EUR, depending on the duration of weaning-successful conception period. Duarte et al.concluded that this price should be from 38-53 EUR which suggests an answer to the question why piglet production in Serbia is unprofitable and piglet farms are in an unenviable situation (14).

\section{CONCLUSION}

Establishing economic effect in intensive piglets production is very complex and complicated job. Production economy is affected by many factors. One of the most important factors for the economical production is participation price of food used for feeding sows. The value of food annually directly affects the cost of piglets. Also, one of the most important factors in the formation of the cost price of piglets is the price of one feeding day of sows. The direct impact of the cost of feeding day is reflected in the fact that with increasing number of feeding days proportionally increases the cost of piglets. Number of piglets per litter is one of the determining factors in the formation of the cost price of piglets. The economic effect at twelve piglets per litter is higher by almost $50 \%$ compared to eight piglets per litter.

\section{REFERENCES}

1. Wolf, J., Wolfovà, M. (2012). Genetic parameters including the service sire effect for the sow traits stillbirth and piglet losses in Czech Large White and Landrace. Czech Journal of Animal Science 57 (9): 402-409.

2. Menčik, S., Vuković, V., Modrić, M., Špehar, M., Ostović, M., Sušić, V., Štoković, I., Samardžija, M., Ekert Kabalin A. (2015). Prlr-Alui gene Polymorphism and litter size traits in highly prolific line of topigs 20 Sows. Acta Veterinaria 65 (4): 463-476.

http://dx.doi.org/10.1515/acve-2015-0039

3. Mirilović, M., Tešić, M., Pejin, I., Rogožarski, D., Krstić, B. (2012). Economics and management in hog raising. Contemporary Agriculture 61 (3-4): 192-198. (In Serbian)

4. Vlahović, B., Štrbac, M. (2008). Trends in pig meat production in Europe. Contemporary Agriculture 57 (1-2): 70-76. ( In Serbian)

5. Quendler, E., Podiwinsky, C., Baumgartner, J., Winckler, C., Boxberger, J. (2009). Performance, labour and economic aspects of different farrowing systems. Agricultural Engineering International: the CIGR Ejournal. Manuscript MES 1135, 9, 1-10. 
6. Ostović, M., Pavičić, Ž., Tofant, A., Balenović, T., Ekert Kabalin, A., Menčik, S., Antunović, B., Marković, F. (2010). Teat sanitation in lactating sows. Acta Veterinaria 60 (2-3): 249-256. http://dx.doi.org/10.2298/AVB1003249O

7. Marois, D., Brisbane, J.R., Laforest, J.P. (2000). Accounting for lactation length and weaningto-conception interval in genetic evaluations for litter size in swine. J. Anim. Sci. 78, 1796-1810. PMid:10907821

8. Stančić, B., Radović, I., Gagrčin, M. (2000). Interval zalučenje-estrus i njegov uticaj na fertilitet krmača. Journal of Scientific Agricultural Research 61 (3): 85-92.

9. Radović, Ivan., Stančić, B.L., Timotijević, M., Gagrčin, M. (2003). The effect of parity and weaning estrus on fertility of sows. Contemporary Agriculture 52 (3-4): 251-256. ( In Serbian)

10. Mirilović, M. (2013). Biostatistika sa informatikom. In: Praktikum, Biostatistika sa informatikom (pp.81-99). Beograd: Fakultet veterinarske medicine.
11. Sprysl, M., Citek, J., Stupka, R. (2010). Interaction of selected production indicators of the economics of pork production, Czech Journal of Animal Science $55,1-10$.

12. Aherne F., Kirkwood R. Factors affecting litter size. Pig Articles from The Pig Site, 2001 [cited 2015 May 16]. http://www.thepigsite.com

13. Plà-Aragonès, L.M., Flores Marias, V., RodríguezSánchez, S.V. (2008). A simulation model for intensive piglet production systems. Proceeding WSC '08 Proceedings of the 40th Conference on Winter Simulation, December, 07-10, (pp.2871-2875), Miami, FL, USA

http://dx.doi.org/10.1109/wsc.2008.4736408

14. Duarte, J.L., Hernández-García, F.I., García-Gudio, J., Rodríguez-De Ledesma, A., Izquierdo, M. (2013). The effect of farrowing rate and number of piglets weaned per litter on production costs of commercial Iberian herds in Extremadura (Spain). Acta argiculturae Slovenica 4, 215-218.

Please cite this article as: Mirilović M., Velebit B., Djurić S., Vejnović B., Dimitrijević M., Tajdić N., Rogožarski D. Determination of the economic effects in intesive production of piglets. Mac Vet Rev 2016; 39 (2): 233-238. http://dx.doi.org/10.1515/macvetrev-2016-0090 